Piśmiennictwo zakonne $w$ dobie staropolskiej, red. Magdalena Kuran, Katarzyna KaczorScheitler i Michał Kuran, przy współpracy Dawida Szymczaka, Łódź 2013.

JaKUB Z. LiChaŃsKi ${ }^{1}$ Uniwersytet Warszawski

\title{
Początki dyskursu akademickiego. Jezuickie Assertiones
}

\author{
Sięga się po retorykę nie tylko po to, \\ by poznać same jej zasady, lecz by je zastosować. \\ Asseriones rhetoricae (1577), cap. XV
}

\section{Streszczenie}

Celem artykułu jest przedstawienie dwu problemów: po pierwsze - początków kształtowania dyskursu akademickiego w nowożytnej Europie, po drugie — opisanie jezuickich Assertiones, które można uznać za wstęp do nowoczesnego dyskursu naukowego. Autor przedstawia najpierw kształtowanie Assertiones, ich formę oraz zakres tematyczny. Następnie pokazuje, iż wypełniają one zadania, jakie stawiamy dziś przed dyskursem akademickim. Badacz zwraca także uwagę, iż pełen opis Assertiones jest utrudniony, bowiem brakuje nam zapisu dyskusji, jaka odbywała się po prezentacji tez zawartych w Assertiones. W konkluzji autor stwierdza, iż nie tylko można uznać Assertiones za specyficzna formę wypowiedzi naukowej w szkołach jezuickich, za formę dyskursu akademickiego, ale iż Assertiones znacząco wpłynęły na późniejszy kształt dyskursu akademickiego.

\section{Early Academic Discourse. The Jesuit Assertiones}

Is reach for the rhetoric not only to learn its rules, but to apply them. Asseriones rhetoricae (1577), cap. XV

\section{Summary}

The purpose of the article is to discuss two problems: first, early academic discourse in shaping the modern Europe, secondly to describe the Jesuit Assertiones, which can be considered an introduction to modern scientific discourse. The author presents the first evolution of Assertiones, the form and scope. Then fill in what we know today in academic discourse. The investigator also notes that a full description of Assertiones is difficult, because the discussion entry is missing, what was after presentation is also

\footnotetext{
${ }^{1}$ Prof. dr hab. Jakub Z. Lichański (ur. 1946) pracownik Uniwersytetu Warszawskiego. Jest specjalistą w zakresie historii literatury oraz retoryki, a także średniowiecznych iluminowanych rękopisów astrologicznych, historii opraw książkowych (średniowiecze-barok) oraz literatury i kultury popularnej, szczególnie literatury SF i Fantasy. Przez kilka lat był stypendystą Królewskiego Uniwersytetu w Uppsali, gdzie kontynuował m.in. prace zapoczątkowane przez profesora Józefa Trypućkę nad dziejami polskich bibliotek wywiezionych do Szwecji. Jest członkiem m.in. Polskiego Towarzystwa Filologicznego, The International Society for the History of Rhetoric, Polskiego Towarzystwa Retorycznego; należy do grona autorów Historisches Wörterbuch der Rhetorik wydawanego przez Uniwersytet w Tybindze.
} 
contained in Assertiones. In conclusion the author finds that not only can Assertiones be a specific form of scientific expression in Jesuit schools, form of academic discourse, but that Assertiones significantly influenced later shape academic discourse.

\section{WsTęP}

Dyskurs akademicki nie narodził się w XIX ani tym bardziej w XX wieku; jego źródeł poszukiwałbym daleko wcześniej, bowiem jest on nieodrodnym dzieckiem kształcenia uniwersyteckiego ${ }^{2}$. Zapewne zatem jego początki sięgają XI wiekuª ; tu jednak odwołam się do pewnej jego postaci, jaka pojawiła się w kolegiach jezuickich przed wprowadzeniem Ratio studiorum, a po jego wprowadzeniu nadal istniała, jako właśnie forma dyskursu akademickiego [Theses haec Rhetoricae, ut ad disputandum proponantur et typis excudantur, dignae a me iudicatae sunt (Tezy tej retoryki, zaproponowane do dysputy oraz wydrukowane, uznałem za warte rozważenia). Wolfgangus Zettelius, Academiae Professor — podkr. J. Z. L.] $]^{4}$.

\section{ASSERTIONES W EDUKACJI JEZUICKIEJ}

Nauczanie różnych przedmiotów, w tym m.in. retoryki, w kolegiach jezuickich odbywało się na podstawie wskazań zawartych w Ratio studiorum, ale też i w pracach Antonio Possevina, głównie w jego dziele Bibliotheca selecta oraz — w odniesieniu do retoryki - podręcznika Cypriana Soareza5. Uwaga ta jednak, acz oczywista, wymaga pewnych uściśleń. Należałoby powiedzieć, iż książka Soareza była podstawowym kompendium; sięgano jednak też do innych opracowań, głównie zresztą prac Marka

\footnotetext{
${ }^{2}$ Por. P. Bizzell, Academic Discourse and Critical Consciousness, Pittsburgh: Univ. of Pittsb. Press, 1992, passim. W swej książce wskazuje na tradycję właśnie szkoły jezuickiej, która uczyła — poprzez nauczanie retoryki - właśnie protodyskursu akademickiego. M. Feingold, Jesuit Science and the Republic of Letters, Cambridge, MA: MIT Press, 2003.

${ }^{3}$ Wraz z powstaniem uniwersytetów - Bolonia (1088), Paryż (ok. 1150), Oxford (1167), że pominę uniwersytety w Konstantynopolu (V w. ne), Salerno czy Ohridzie (datowane na IX w.), por. Walther Rüegg, wyd., A History of University in Europe, t. 1-3, Cambridge: Cambridge Univ. Press, 1992-2004, t. 1, Universities in the Middle Age.

${ }^{4} \mathrm{~V}$. Rotmar, Assertiones rhetoricae, Ingolstadii 1575, k. A ${ }^{4 \mathrm{r}}$ [VD16, R 3333: BSB-Katalog - 4 Diss. 3487, 32].

${ }^{5}$ Zob. Ratio atque Institutio Studiorum SJ czyli Ustawa Szkolna Towarzystwa Jezusowego (1599), wstęp, oprac. K. Bartnicka, T. Bieńkowski, Warszawa 2000 [Archiwum Dziejów Oświaty, t. 13]; A. Possevino, Bibliotheca selecta, Colonia Agrippina 1607; ale tenże, Apparatus sacer, t. 1-3, Venetiis 1606; C. Soarez, De arte rhetorica lib. III, Coimbre 1562; także B. Bauer, Jesuitische ,ars rhetorica” im Zeitalter der Glaubenskämpfe, Frankfurt am Main 1986; R. Darowski SJ, Filozofia w szkołach jezuickich w Polsce w XVI wieku, Kraków 1994; por. także literaturę podaną w przyp. 2. Jednakże problemy te, jak pokazuje studium Christiana Mouchela (zob. C. Mouchel, La rhétorique post-tridentiens (1570-1600): la fabrique d'une société chrétienne, [w:] Histoire de la rhétorique dans l'Europe moderne: 1450-1950, red. M. Fumaroli, Paris 1999, s. 431-497), są niezwykle złożone i nim definitywnie reguły Ratio studiorum rozstrzygną, jak i po co uczyć retoryki, będą podejmowane, szczególnie we Włoszech oraz Francji, próby niezależnego ukształtowania nie tyle teorii retoryki, co sposobów jej uczenia. Także — jak bogata ma być tradycja innych tekstów, które uczeń winien poznać. Cytowany dalej A. Valier, proponuje niezwykle bogaty zestaw lektur / ćwiczeń dla adepta retoryki [obejmuje on m.in. najważniejszych Ojców greckich i łacińskich].
} 
Tulliusza Cycerona, trzeba przypomnieć, iż głos decydujący, co można było czytać dodatkowo, poza lekturami obowiązkowymi, mieli profesor wykładający dany przedmiot oraz prefekt studiów ${ }^{6}$.

Poza wskazanymi książkami istotną rolę odgrywały, w okresie przed wprowadzeniem ostatecznej wersji Ratio studiorum (1599), Assertiones. Były to, zgodnie z ogólnymi przepisami dotyczącymi nauczania w szkołach jezuickich, tezy (twierdzenia) przygotowane do publicznej dysputy na określony temat ${ }^{7}$. Zakres tematyki wyznaczał profesor prowadzący dany przedmiot; dysputy dotyczyły przede wszystkim kwestii filozoficznych bądź teologicznych. Dyskusje z zakresu retoryki były rzadkie i są — ze względu na specyfikę przedmiotu — bardzo interesujące ${ }^{8}$. Dodać wreszcie trzeba, iż cel nauczania retoryki był czysto praktyczny; jak powiada współczesny badacz?: „Retoryka stanowiła szczyt i cel nauczania w klasycznej szkole jezuickiej. Absolwent [...] miał być doskonałym oratorem [...]".

Można śmiało powiedzieć, iż miała nauka téchne rhetoriké mieć charakter ważny, acz pomocniczy i instrumentalny. Warto zatem spróbować pokazać, na konkretnym przykładzie, iż przynajmniej w wieku XVI, dostrzegali uczeni jezuiccy złożoność problemów tyczących „sztuki słowa”.

${ }^{6}$ Cf. Ratio studiorum, Reguty profesora retoryki [zaleca się w nich korzystanie głównie z pism M. T. Cycerona] oraz Reguty prefekta studiów; także B. Otwinowska, Cyceronianizm, [w :] Stownik literatury staropolskiej, red. T. Michałowska, współpr. E. Sarnowska-Temeriusz, B. Otwinowska, Wrocław 1990, s. 113118; najpełniejsze informacje w: F. Tateo, Ciceronianismus, [w:] Historisches Wörterbuch der Rhetorik, wyd. G. Ueding, W. Jens, red.: G. Kalivoda, H. Mazer, F.-H. Robling, Tübingen 1994, vol. 2, kol. 225-239. Należy dodać, iż analiza zbiorów bibliotek kolegiów jezuickich pokazuje, iż dział: Retoryka w tychże księgozbiorach był dość bogaty, por. L. Grzebień, Organizacja bibliotek jezuickich w Polsce od XVI do XVIII wieku, „Archiwa, Biblioteki i Muzea Kościelne” 1975, t. 30-31, [t. 30, s. 223nn, t. 31, s. 225nn]; J. Z. Lichański, Biblioteka „Collegium Societatis Iesu” w Braniewie. Próba charakterystyki, „Studia Warmińskie”, R. 27: 1990, s. 309-323, il.; tenże, Brunsbergica Pallas. Uwagi na marginesie historii bibliotek i nauki $w$ dobie Renesansu, „Odrodzenie i Reformacja w Polsce”, R. 41: 1997, s. 111-112.

${ }^{7}$ Zob. R. Darowski SJ, dz. cyt., s. 27-32; 52-53 nn. W Aneksie, który wykorzystuje Bibliografiępolską K. Estreichera, pokazuję ile i o jak różnorodnej tematyce prac typu Assertiones powstało, głównie w XVI i XVII wieku. ${ }^{8}$ Zbiór takich twierdzeń przedstawiony do publicznej dyskusji w październiku 1577 roku w Kolegium S.I. w Poznaniu jest wyjątkowo interesujący — ze względu na wspomniane wcześniej kwestie filozoficzne; nie jest to jednak jedyny zbiór takich tez. Były one jeszcze prezentowane w latach 1580 i 1582 . Szerzej, zob. J. Z. Lichański, Recepcja retorów greckich $w$ Polsce $w$ XVI i XVII wieku w nauczaniu szkolnym, [w:] Retoryka antyczna i jej dziedzictwo, red. M. Grzesiowski, Warszawa 1996, s. 115-126 [Acta Societatis Philologae Polonorum, 2]. Por. też R. Darowski SJ, dz. cyt., s. 27-32, 256nn, 260nn.

${ }^{9}$ Zob. L. Grzebień SJ, Dotychczasowa literatura o wkładzie jezuitów polskich do nauki i kultury, [w:] Wkład jezuitów do nauki i kultury, red. I. Stasiewicz-Jasiukowa, Kraków-Warszawa 2004, s. 54. Wcześniej, w haśle: Retoryka, [w:] Encyklopedia wiedzy o jezuitach na ziemiach Polski i Litwy 1564-1995, red. L. Grzebień SJ, Kraków 1996, zwrócono uwagę, iż: „Ordo studiorum” Jakuba Ledesmy określa zadania klasy [retoryki]: »w mowie wykwintność, w piśmie obfity dobór słów, a zawsze płynność i potoczystość»". Podobnie kwestie te ujmował M. Korolko w: tenże, Retoryka w polskich kolegiach jezuickich, [w:] Jezuici a kultura polska, red. L. Grzebień, SJ, St. Obirek, SJ, Kraków 1993, s. 121-142. 


\section{ASSERTIONS JAKO FORMA WYPOWIEDZI NAUKOWEJ ${ }^{\mathrm{IO}}$}

\section{Zacznę od przytoczenia słów Romana Darowskiego:}

W wykładach profesorowie stosowali metodę scholastyczną. Było to oparte przede wszystkim na prezentacji materiału w postaci sporu, w którym istotną rolę odgrywały tzw. tezy (thesis), lub pytania (quaestio). Składała się ona zwykle z następujących części: sformułowanie tezy, wstępna odpowiedź, czyli potwierdzenie tez, analiza stosowanej terminologii, tj. wyjaśnienia i rozróżnienie pojęć (terminorum explicatio), różne stanowiska wobec przedmiotu dyskusji i wyjaśnienia ich bezzasadności (użyte zostają tu m.in. sententiae, adversaria), przedstawienie prawdziwości tezy w formie sylogizmów (probatio), teoretyczne konsekwencje udowodnienia tezy (corollaria), zagadnienia uzupełniające (scholia). Oczywiście, tylko w pełni rozwinięte tezy posiadały wszystkie części. Filozofia zatem kształtowała się poprzez dyskusje, ale podstawą były: dydaktyka, czyli wykłady, dla których bazę stanowiły drukowane podręczniki, a także Tezy / Assertiones i rękopiśmienne wykłady. Taka sytuacja jest szczególnie w wieku XVII; poziom tych zajęć często nie imponuje, jeśli chodzi o kształcenie w zakresie logiki, i dotyczy to nie tylko uczniów, ale także profesorów. Warto jednak podkreślić, iż w dydaktyce ważną rolę odgrywały różne formy ćwiczeń i powtórzeń polemicznych (disputationes). Dużą wagę przywiązywano do umiejętności analizy i jasnego rozróżnienia (oportet distinguere) pojęć i terminów w dyskusji i polemikach. Początków niektórych działów współczesnej logiki formalnej można śmiało szukać w niektórych pracach, szczególnie w rękopisach wykładów z logiki i dialektyki. Ten rodzaj dydaktyki — pomimo różnych zastrzeżeń, które można mu przeciwstawić — stanowi doskonałe wprowadzenie do myślenia abstrakcyjnego.

(Roman Darowski, <http://www.filosofija.vu.lt/500/darowski.pdf>)

A zatem można śmiało powiedzieć, iż właśnie Tezy/Assertiones są sformalizowaną formą dyskursu akademickiego. Istotnym ich uzupełnieniem są Dysputy ${ }^{11}$ :

DYSPUTY (Disputationes) to rodzaj dyskusji z filozofii, teologii i przedmiotów humanistycznych, organizowane w szkołach jezuickich dla utrwalenia przerobionego materiału. Zwykłe dysputy należało organizować z każdego przedmiotu przynajmniej raz w tygodniu. 3 lub 4 razy w roku urządzano dysputy uroczyste, dostępne dla wszystkich, również dla zapraszanych gości z zewnątrz. Dysputy organizował prof. przedmiotu, a nadzorował prefeekt studiów i rektor. Programy uroczystych dysput z tezami przewidzianymi do obrony (Assertiones, Propositiones, Theses) były często drukowane i rozdzielane uczestnikom. Wiele z nich zachowało się do dziś w bibliotekach polskich. Najstarsze z XVI wieku z kolegium w Braniewie przetrwały w Biblioteces Uniw`ersyteckiej s w Uppsali. Zasady i sposoby organizowania dysput zawarte były w regułach poszczególnych profesorów i prefektów szkół. Dysputy ożywiały działalność szkół, podnosiły ich poziom i przynosiły wiele atrakcji uczniom. Wbrew pojawiającej się czasem opinii autorami tez na dysputy nie byli studenci broniący ich, lecz profesor wykładający dany przedmiot.

Dyskurs akademicki został ukształtowany w szkolnictwie jezuickim; stanowiły go dwa elementy: Assertiones, jako forma pisemna, oraz Disputationes, jako ich konieczne ustne uzupełnienie.

Przyjrzyjmy się teraz karcie tytułowej Assertiones, bowiem wyjaśnia ona sposób przebiegu dyskusji akademickiej. Zawarta jest tam informacja na temat miejsca oraz

\footnotetext{
${ }^{10}$ Zob. R. Darowski SJ, Philosophy of Jesuits in Lithuania since the 16th until the 18th century [online], dostęp: 16 września 2010, dostępny: <http://www. filosofija.vu.lt/500/darowski.pdf>. Willima W. Rockwell, The Jesuits as Portrayed by Non-Catholic Historians, "Harvard Theological Review", R. 7: 1914, nr 3, s. 358-377, szczeg. s. 376-377.

${ }^{11}$ Dysputy, [w:] Encyklopedia wiedzy o jezuitach... [online], s. 607-608, dostęp 16 września 2010, dostępny: <http://www.jezuici.krakow.pl/cgi-bin/rjbo?b=enc\&q=DYSPUTY\&f=1,()>.
} 
czasu odbycia dyskusji. Materiał wydrukowany zawiera podstawowe tezy, które będą przedmiotem sporu. Pokażę to na konkretnym przykładzie.

Assertiones rhetoricae z 1577 są tekstem, jak na takie wydawnictwo, bardzo obszernym i dotyczą nie tylko samej retoryki, jak na przykład Assertiones z 1580 i 1582 roku ${ }^{12}$, ale są także próbą opisu jej miejsca w systemie nauk. Jest to o tyle istotne, że autor stara się określić specyfikę retoryki w odniesieniu nie tylko do dialektyki, ale ogólnie do filozofii oraz do logiki. Przeanalizujmy zatem treść twierdzeń.

Zacznijmy od odnotowania, że z 15 rozdziałów broszury aż 12 [sic!] poświęconych jest opisowi kwestii wiążących się z usytuowaniem retoryki wobec: dialektyki, filozofii, logiki. Osobnym problemem jest także umieszczenie retoryki w obrębie jednego z rodzajów sztuk, a także określenia, jaką sztuką jest retoryka (jeśli przyjmujemy, że jest ona m.in. sztuką) $)^{13}$.

Przedstawię teraz kilka kwestii omawianych w Assertiones, aby przybliżyć zakres problemów w nich poruszanych. Autor rozpoczyna ${ }^{14}$ swe rozważania od przypomnienia, że retoryka jest określana jako: sztuka (ars), dyscyplina naukowa (scientia), cnota (virtus), biegłość (usus), umiejętność (facultas). Za najlepiej charakteryzujące retorykę przyjmuje autor dwa określenia: ars i facultas ${ }^{15}$. Jednakże taki pogląd sugeruje, że retoryka jest odpowiednikiem dialektyki; różnią się rodzajem wypowiedzi, jaki zostaje przez nie przygotowany. Podobieństwa między nimi tkwią $\mathrm{w}^{16}$ :

\footnotetext{
${ }^{12}$ Zob. Assertiones [...] rhetoricae, Poznań 1580; na ich temat, por. R. Darowski SJ, dz. cyt., s. 256. Same twierdzenia są bardzo zwięztym komentarzem do Arystotelesa, na co wskazuje już tytuł: Rhetoricae [Assertiones] ex tribus Aristotelis De arte rhetorica libris. Komentarz to dość osobliwy, bowiem mowa w nim jest o oratorstwie a nie retoryce, a sam wykład jest miejscami zaskakujący (np. według autora komentarza mowa ma dwie części, w wykładzie nauki o periodzie zostaje dość niespodziewanie przywołany Hermogenes, a sam period częściowo jest utożsamiany z oddechem, rytm prozy wiązany jest z miarami: jambiczną i trocheiczną (czyżby dalekie echo uwag M. T. Cycerona z tegoż Orator, 191 sqq?), itd. Assertiones rhetoricae..., Poznań 1582; na ich temat por. R. Darowski SJ, dz. cyt., s. 260-261 (według tego badacza ich autorem nie jest A.W. Faunt SJ). Same twierdzenia dotyczą wyłącznie wybranych kwestii z... De oratore M. T. Cycerona. Podobną sytuację mamy w wypadku Assertiones in Gymnasio Vilnensi Societatis Iesu... Rhetoricae..., Wilno 1577, gdzie komentarz dotyczy wyłącznie dialogu M. T. Cycerona Orator.

${ }^{13}$ Pełna analiza, wraz z komentowanym tekstem w: J. Z. Lichański, Retoryka: od renesansu do wspótczesności - tradycja i innowacja, Warszawa 2000, s. 44-61, tu także ustalenie autorstwa Assertiones..., Poznań 1577; był nim Johann/Jan Wierus.

${ }^{14}$ Zob. Assertiones... 1577. cap. I i II. Autor odwołuje się do: Quint., 2.16; Cic., Orat., 114, 117. Por. też: Quint., 2.17.37; tamże, 2.14.5; tamże, Orig., 2,1.1.; Arist., Eth. Nic., 2.4. 1106 a 12. Nb. A. Valier, De Rhetorica ecclesiastica, Verone 1574, s. 2 (Rhetorica est ARS sive FACULTAS inveniendi, disponendi et eloquendi - podkr. J. Z. L.; tekst ten powstał z inspiracji Karola Boromeusza). Także Arist., rhet., I.1.1354 a 1; Cic., Orat., 114-115; Herm., Stat., 3.90; Cic., Inv., 2.7.24. Zob. też J. Martin, Antike Rhetorik. Technik und Methode, München 1974, s. 5-6.

${ }^{15}$ Zob. Assertiones... 1580, k. $\mathrm{B}_{4} \mathrm{r}$ („Artis et facultatis oratoriae, quae quasi ex altera parte respondet Dialectcae [...]”). Pogląd ten zatem można przyjąć jako stałą opinię w jezuickim nauczaniu retoryki.

${ }^{16}$ Zob. Assertiones... 1577, cap. III. Warto tu podkreślić, że słówko antistrophos znaczy: „odpowiednik”, acz słuszniej byłoby je tłumaczyć jako: „analogiczny(a)”; zob. też L. D. Green, Aristotelian Rhetoric, Dia-

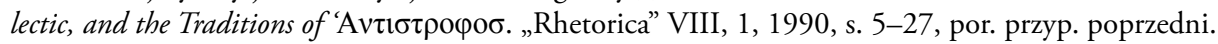


[...] przynależności [przez nie — dop. J. Z. L.] do pośredniej kategorii; posługiwać się nimi możemy i dobrze i źle; [...] tylko te dwie sztuki zalecają właściwą metodę roztrząsania tej samej rzeczy w zgoła odmienny sposób.

Owa odmienność tkwiła w fakcie, że wypowiedzi dialektyczne porównują, zestawiają różne opinie, podczas gdy retoryczne mają stanowić zachętę do podjęcia konkretnego działania. Niezwykle ważna jest następna uwaga tycząca rodzajów dowodów, jakimi posługują się obie nauki: oto zdaniem autora ich domeną nie są dowody ścisłe (użyte zostaje tu określenie — orismenai), ale dowody oparte na domniemaniach (pada tu określenie — stochastikos) ${ }^{17}$. Autorowi Assertiones chodzi o rozróżnienie dowodzeń opartych na: definiowaniu pojęć (właśnie tak należy rozumieć kategorię — orismenai), bądź na przypuszczeniach, domysłach, domniemaniach, uogólnieniach, prawdopodobieństwach (tak zapewne jest rozumiana kategoria — stochastikos; zwracam uwagę, że jest ona definiowana według rozumienia sugerowanego przez Galena w De Hippocratis et Platonis decretis libri novem ${ }^{18}$. W ten sposób autor określa też dodatkowo różnice, jakie dzielą retorykę od logiki: ta ostatnia zajmuje się bowiem, jak powiedzielibyśmy dzisiaj, rozumowaniami niezawodnymi, a stawiane przez nią pytania dotykaja, in summa, tez (=kwestii ogólnych). Przedmiotem retoryki pozostają wyłącznie hipotezy (=kwestie szczegółowe $)^{19}$. Uzupełniając wcześniejszą uwagę na temat typów dowodów używanych przez dialektykę i retorykę, autor rozpatruje także rozróżnienie dwu rodzajów rozumowań prawdopodobnych: jeden — określany jako pithanon — przypisuje retoryce, drugi — określany jako endoxon - przypisuje dialektyce ${ }^{20}$. Różnica polega na tym, że pierwszy rodzaj odwołuje się do wiary, drugi do powszechnie przyjętych opinii.

${ }^{17}$ Zob. Assertiones... 1577, cap. III. autor odwołuje się do: Arist., Eth.nic., 1.13 .1102 a 5-1103 a 10; Plato, Phaedr., 272 D-273 E; Arist., top., 1.12 .105 a 10; Alex. Aphrod., Scholia ad Arist. Top.; Galen, De Hippocrtais et Platonis decretis libri novem. Problem ten w teorii retoryki wygląda jednak nieco inaczej, por. J. Klein, Beweis, Beweismittel, [w:] Historisches Wörterbuch der Rhetorik, Tübingen 1992, t. 1, kol. $1528-1548$.

${ }^{18}$ Zob. C. Galenus, Opera omnia..., t. 1-11, Basileae 1562, t. 1, s. 592 H. Problematyka tego tekstu jest bardziej złożona, niż wskazuje tytuł; wiąże się to zresztą z pytaniem o poglądy Galena na kwestie logiczne, bowiem wydaje się, iż pomiędzy sądami tu wskazanymi, a znanymi z Galen, Wstęp do dialektyki, przekł. J. Świderek, Lublin 1999 [na podstawie rękopisu Cod. Parisini Suppl. 635] lub omówionymi wcześniej np. w pracy Jamesa W. Stakeluma (zob. tenże, Galen and the Logic of Proposition, Romae 1940 — zachodzą spore różnice). Pisma filozoficzne, gramatyczne i retoryczne Galena omówione w haśle Galenos, [w:] $R[$ eal $]$ E[ncyclopädie der klassischen Altertumswissenschaft], Stuttgart 1910, t. VII.13, kol. 587-589. Warto jednak przypomnieć, iż C. Prantl w: Geschichte der Logik im Abendlande (1855), Berlin 1955, s. 559-577 wskazuje na kwestie dla nas ważkie a wiążące się z poglądami Galena na kwestie tyczące związków retoryki, logiki oraz... medycyny w zakresie rozumowań opartych na prawdopodobieństwie. Problem tu wskazany będzie zresztą przedmiotem osobnych rozważań.

${ }^{19}$ Jest to podstawowe rozróżnienie (na tezy i hipotezy) znane z najstarszych traktatów retorycznych, por. R. Volkmann, Wprowadzenie do retoryki Greków i Rzymian, przekł. L. Bobiatyński, oprac. H. Cichocka, J. Z. Lichański, Warszawa 1993, s. 131 nn.; J. Martin, dz. cyt., s. 15 nn.

${ }_{20}$ Zob. Assertiones... 1577, cap. XI. Rozróżnienie to wprowadził już Arystoteles, por. Arist., Eth.nic., 1172 b 36 (1173 a 1-3); także Ariet., Top., 100b21sqq; omówienie problemu w: P. Ptassek, Endoxa, [w:] Historisches Wörterbuch der Rhetorik, t. 2, Tübingen 1994, kol. 1134-1135. 
Jak zatem widać, treści do dyskusji mogą być niezwykle obszerne i wymagać od uczestników nie byle jakiego merytorycznego przygotowania. Nie wystarczy już tylko znajomość tekstów na przykład Marka Tulliusza Cycerona; tu trzeba dobrze znać całość teorii oraz historię retoryki.

\section{ASSERTIONES I DYSKURS AKADEMICKI ${ }^{2 \mathrm{I}}$}

Dyskurs akademicki jest dziś definiowany bardzo różnie. Podstawowe określenie podsuwa oczywiście Teun A. van Dijk mówiąc, iż jest to zarówno pewna struktura, jak i proces ${ }^{22}$; chodzi tu o ukazanie dyskursu nie tylko jako konstrukcji językoznawczej, ale — szerzej — jako sposobu wykorzystania owej/owych struktur w praktyce ${ }^{23}$. David Bartholomae sugeruje, iż są to m.in. „różne rodzaje sposobów pisania, ale i prezentowania swych poglądów na uniwersytecie”; co więcej — my tychże „typów dyskursu” uczymy i wymagamy, trochę jak form rytualnych ${ }^{24}$. Natomiast Stanisław Gajda zwraca uwagę, iż samo pojęcie „nie jest stabilne, mamy raczej do czynienia z całą rodziną znaczeń starszych i nowszych, kształtowanych na różnych obszarach badań i w różnych celach”. W jego ramach wyróżnia się m.in.: dyskurs nauk ścisłych, dyskurs nauk humanistycznych (dyskurs humanistyczny) i w ich obrębie dyskursy poszczególnych dyscyplin. Oprócz tego występują dyskursy nienaukowe: potoczny, publicystyczny, polityczny, ideologiczny, autobiograficzny, prasowy, telewizyjny i inne ${ }^{25}$. Niektórzy badacze pragną jeszcze w to pole wprowadzić problematykę aksjologiczną - co jest słuszne, ale szalenie komplikuje i tak wystarczająco złożoną sytuację. Jednak w tych rozważaniach interesująco jest definiowany sam dyskurs; jest on, zdaniem ${ }^{26}$, „wy-

${ }^{21}$ Zob. Linda-Ruth Dyck, Redefined Rhetoric: Academic Discourse and Aboriginal students [online], dostęp: 16 września 2010, dostępny: <http://www.cst.ed.ac.uk/2005conference/papers/Dyck_paper.pdf >.

${ }^{22}$ Zob. Dyskurs jako struktura i proces, red. T. A. van Dijk, przekł. G. Grochowski, Warszawa 2001.

${ }^{23}$ Pomijam złożoną problematykę „krytycznej analizy dyskursu” (critical discourse analysis), bowiem nadmiernie by poszerzyła pole naszych obserwacji, zob. przywoływaną dalej pracę A. Duszak oraz N. Fairclougha. Ten ostatni sugeruje, iż właśnie w analizie „dyskursu” musimy zbadać „ukryte” relacje pomiędzy (a) „tekstami, zdarzeniami i praktykami dyskursywnymi oraz (b) szerszymi strukturami, relacjami i procesami społecznymi i kulturowymi”. Szerzej zob. też B. Jabłońska, Krytyczna analiza dyskursu: refleksje teoretyczno-metodologiczne, „Qualitative Sociology Review — Edycja Polska” [online], t. 2, nr 1, s. 53-67, dostęp: 6 lutego 2009, dostępny: <www.qualitativesociologyreview.org/PL/archive_pl/php:> w tym artykule także częściowy przegląd polskiego stanu badań wspomnianego zagadnienia. Najpełniej kwestie są przedstawione w najnowszym studium T. A. van Dijka, Discourse and Context. A Sociocognitive Approach, Cambridge: Cambridge Univ. Press, 2008.

${ }^{24}$ Zob. D. Bartholomae, Inventing the University, "Journal of Basic Writing”, R. 5: 1986, s. 11.

${ }_{25}$ Zob. S. Gajda, Wspótczesny polski dyskurs naukowy, [w:] Dyskurs naukowy — tradycja i zmiana, red. St. Gajda, Opole 1999, s. 9-17. Także tenże, Podstawy badań stylistycznych nad językiem naukowym, Warszawa 1982; A. Duszak, Tekst, dyskurs, komunikacja międzykulturowa, Warszawa 1998; Krytyczna analiza dyskursu: interdyscyplinarne podejście do komunikacji spotecznej, red. A. Duszak, N. Fairclough, Kraków 2008.

${ }^{26}$ Takie kwestie omawia m.in. Piotr Czajka, zob. tenże, Human Needs as Expressed in Educational Discourse on the Basis of Textbooks in Linguistics, [w:] Exploring the Domain of Human-Centered Linguistics from a Hard-Science Perspective, red. V. H. Yngve, Z. Wąsik, Poznań 2000, s. 36-38. (streszcz. rozprawy: Dyskurs akademicki w perspektywie aksjologicznej na przykładzie podręczników językoznawstwa). Jak powiada autor: „Celem dysertacji było wypracowanie takiej koncepcji połączenia aksjologii z językoznawstwem, 
tworem celowego działania ludzkiego polegającego na użyciu znaków i jest związany z wartościami dzięki temu, iż jego wytworzenie umotywowane może być odczuwaną subiektywnie potrzebą". Warto przypomnieć, iż autorzy hasła w Dictionnaire de linguistique orzekają trochę inaczej ${ }^{27}$; według nich „dyskurs to język w użyciu, język wykorzystany przez podmiot mówiący”. Jednak, ponieważ wśród przywoływanych przez nich badaczy znajdują się strukturaliści, oba określenia można przyjąć za uzupełniające się.

Przy takim rozumieniu dyskursu akademickiego okazuje się, iż jego początkiem są właśnie Assertiones oraz Disputationes, ale rozpatrywane razem, a nie oddzielnie. Można zaryzykować tezę, iż w dalszym ciągu kontynuujemy tradycję dydaktyczną szkoły humanistycznej, której jednym z wcieleń tylko była szkoła jezuicka. Taki wniosek może wydawać się szokujący, ale fakty są raczej bezlitosne.

\section{KonKLUZJe}

Czy zatem nasze szkolnictwo, zwłaszcza akademickie, nie rozwinęło się od czasów Johanna Sturma, a następnie dydaktyków jezuickich? Przedstawione rozważania zdają się taką tezę potwierdzać. Przedstawione dalej tabele pokazują, tabele 1 i 3 tradycyjne ujęcie problemów stopni wyboru w dyskursie akademickim, a tabela 2 i 4 - prawidłową konstrukcję stopni wyboru.

Fig. 1: stopnie wyborów w dyskursie akademickim

$$
\begin{gathered}
\text { Wybory konwencji } \\
\text { (mechanika: pisownia, interpunkcja, format) } \\
\text { Wybory semantyczne (słowa) } \\
\text { Wybory syntaktyczne (struktura zdania) } \\
\text { Wybory logiczne (organizacja / argumentacja) } \\
\text { Wybory pojęć (idee, znaczenia, odbiorcy, cel) }
\end{gathered}
$$

za: Linda Ruth Dyck

Wskazane przez Lindę Ruth Dyck wybory, jakich dokonujemy w dyskursie akademickim, są podobne do opisanych przez Romana Darowskiego cech Tez jezuickich. Wiążą się także z tradycją retorycznej konstrukcji tekstu, gdzie mówimy o etapach jego kształtowania, a nie o częściach retoryki ${ }^{28}$. Można przeprowadzić następującą paralelę:

która łączyłaby zagadnienia wartości i języka na płaszczyźnie celowego ludzkiego działania nakierowanego na zaspokojenie potrzeb”.

${ }^{27}$ Zob. Dictionnaire de linguistique, red. J. Dubois i in., Paris: Libr. Larousse, 1973, s. 156-159 ([...] le discours est le langage mis en action, la langue assumée par le sujet parlant [...] jest synonimem takich pojęć, jak m.in. parol, énoncê). Określenie to, zasygnalizuję, jest bliskie części badaczy amerykańskich, zob. m.in. S. I. Hayakawa, Sprache im Denken und Handeln, przekł. G. Schwarz, Darmstadt: Vlg. Darmstädter Blätter Schwarz \& Co., 1976, s. 106-124 i in.; K. Burke, A Grammar of Motives, Berkley, Los Angeles, London: Univ. of Calif. Press, 1969, s. 3-124; J. van Bentham, Language in Action. Categories, Lambdas, and Dynamic Logic, Cambridge MA: MIT Press, 1995.

${ }^{28}$ Zob. G. Ueding, Klassische Rhetorik, München: C.H. Beck Vlg., 2000, s. 55-57; także J. Z. Lichański, Retoryka: Historia - Teoria - Praktyka, t. 1-2, Warszawa 2007, t. 1, s. 96. 
Fig. 2: porównanie stopni wyborów w dyskursie akademickim oraz etapów kształtowania tekstu według teorii retoryki ${ }^{29}$

\begin{tabular}{|c|c|c|}
\hline & stopnie wyborów w dyskursie akademickim & etapy kształtowania tekstu wg teorii retoryki \\
\hline 5. & $\begin{array}{c}\text { Wybory konwencji } \\
\text { (mechanika: pisownia, interpunkcja, } \\
\text { format) }\end{array}$ & $\begin{array}{l}\text { Elocutio i Actio } \\
\begin{array}{l}\text { Sposób zapisania tekstu ALE także format jego } \\
\text { prezentacji }\end{array}\end{array}$ \\
\hline 4. & $\begin{array}{c}\text { Wybory semantyczne } \\
\text { (słowa) }\end{array}$ & $\begin{array}{l}\text { Elocutio } \\
\text { Wybór tropów i figur, a także dostosowanie } \\
\text { całości do harmonii tekstu }\end{array}$ \\
\hline 3. & $\begin{array}{l}\text { Wybory syntaktyczne } \\
\text { (struktura zdania) }\end{array}$ & $\begin{array}{l}\text { Elocutio } \\
\text { Dobór konstrukcji składniowych ze względu na } \\
\text { zakładane znaczenia tekstu }\end{array}$ \\
\hline 2. & $\begin{array}{c}\text { Wybory logiczne } \\
\text { (organizacja / argumentacja) }\end{array}$ & $\begin{array}{l}\text { Dispositio } \\
\text { Uporządkowanie organizacji tekstu i porządku } \\
\text { argumentowania }\end{array}$ \\
\hline 1. & $\begin{array}{c}\text { Wybory pojęć } \\
\text { (idee, znaczenia, odbiorcy, cel) }\end{array}$ & \begin{tabular}{l}
\multicolumn{1}{c}{ Inventio } \\
Wybór tematu i określenie jego celu, dostosowane \\
go do odbiorcy i okoliczności, wybór topiki i linii \\
dowodzenia
\end{tabular} \\
\hline
\end{tabular}

J. Z. Lichański / Linda Ruth Dyck

Zestawienie to pokazuje podobieństwa pomiędzy stopniami wyborów w dyskursie akademickim a etapami kształtowania tekstu według teorii retoryki. Jeśli nałożymy na to części tezy, okaże się, że w zasadzie mamy do czynienia z bardzo podobnymi konstrukcjami.

Fig. 3: elementy „tezy” według R. Darowskiego

sformułowanie tezy,

wstępna odpowiedź, czyli potwierdzenie tezy,

analiza stosowanej terminologii, tj. wyjaśnienia i rozróżnienie pojęć (terminorum explicatio),

różne stanowiska wobec przedmiotu dyskusji i wyjaśnienia ich bezzasadność (użyte zostają tu m.in.

sententiae, adversaria),

przedstawienie prawdziwości tezy w formie sylogizmów (probatio), teoretyczne konsekwencje udowodnienia tezy (corollarii), zagadnienia uzupełniające (scholia).

[zamknięcie rozważań]

Dopiero teraz można przedstawić, jak kształtowany jest tekst, w tym dyskurs, zgodnie z tradycją teorii retoryki oraz według zasad konstrukcji tez jezuickich.

\footnotetext{
${ }^{29} \mathrm{~W}$ tabeli 2 kolejność punktów jest świadomie odwrócona; podstawą stopni wyborów w dyskursie akademickim jest nie wybór konwencji (jak przyjęto m.in. w schemacie L. R. Dyck), a wybór pojęć. Zastosowałem tu podobną metodę, jak autorzy podręcznika Principles and Types of Speech Communication, London 1990, s. 45-46 nn. Jest to piramida, która ma uświadomić prawidłową kolejność stopni wyboru $\mathrm{w}$ dyskursie.
} 
Fig. 4: porównanie etapów kształtowania tekstu według teorii retoryki oraz elementów tezy ${ }^{30}$

\begin{tabular}{|c|c|c|}
\hline & elementy tezy & $\begin{array}{l}\text { etapy kształtowania tekstu według teorii retoryki } \\
\text { / stopnie wyborów w dyskursie akademickim }\end{array}$ \\
\hline 5. & [zamknięcie rozważań] & $\begin{array}{l}\text { Elocutio i Actio } \\
\text { Sposób zapisania tekstu, ALE także format jego } \\
\text { prezentacji } \\
\text { [Wybory konwencji (mechanika: pisownia, } \\
\text { interpunkcja, format)] }\end{array}$ \\
\hline 4. & zagadnienia uzupełniające (scholia) & \begin{tabular}{l}
\multicolumn{1}{c}{ Elocutio } \\
Wybór tropów i figur, a także dostosowanie cało- \\
ści do harmonii tekstu \\
[Wybory semantyczne (słowa)]
\end{tabular} \\
\hline 3. & $\begin{array}{l}\text { przedstawienie prawdziwości tezy w formie } \\
\text { sylogizmów (probatio), } \\
\text { teoretyczne konsekwencje udowodnienia tezy } \\
\text { (corollaria), }\end{array}$ & $\begin{array}{l}\text { Elocutio } \\
\text { Dobór konstrukcji składniowych ze względu na } \\
\text { zakładane znaczenia tekstu } \\
\text { [Wybory syntaktyczne (struktura zdania)] }\end{array}$ \\
\hline 2. & $\begin{array}{l}\text { różne stanowiska wobec przedmiotu dyskusji } \\
\text { i wyjaśnienia ich bezzasadności (użyte zostają } \\
\text { tu m.in. sententiae, adversaria), }\end{array}$ & $\begin{array}{l}\text { Dispositio } \\
\text { Uporządkowanie organizacji tekstu i porządku } \\
\text { argumentowania } \\
\text { [Wybory logiczne (organizacja / argumenta- } \\
\text { cja)] }\end{array}$ \\
\hline 1. & $\begin{array}{l}\text { sformułowanie tezy, } \\
\text { wstępna odpowiedź, czyli potwierdzenie tezy, } \\
\text { analiza stosowanej terminologii, czyli wyjaśnie- } \\
\text { nia i rozróżnienie pojęć (terminorum explicatio), }\end{array}$ & $\begin{array}{l}\text { Inventio } \\
\text { Wybór tematu i określenie jego celu, dostosowa- } \\
\text { nie go do odbiorcy i okoliczności, wybór topiki } \\
\text { i linii dowodzenia [Wybory pojęć (idee, zna- } \\
\text { czenia, odbiorcy, cel)] }\end{array}$ \\
\hline
\end{tabular}

J. Z. Lichański / R. Darowski / L. R. Dyck

Podobieństwa wynikają z posłużenia się tym samym narzędziem — teorią retoryki. Jak zatem udało się pokazać, to retoryka jest w ostateczności spoiwem, które powoduje, iż współczesny dyskurs akademicki okazuje się tylko przedłużeniem tradycji Thesis / Assertiones i Disputatio. Różnice, jakie możemy zaobserwować, wynikają z faktu, iż kwestie dotyczące na przykład ukształtowania słownego [p-kty 3 i 4] dla tez jezuickich [ze względu na sposób nauczania i gramatyki, i retoryki] nie były podnoszone jako oczywiste. Także i sposób prezentacji nie był wyodrębniany, bowiem wynikał on także ze znajomości u ucznia szkoły jezuickiej tychże sposobów.

Można zatem śmiało powiedzieć, iż pomiędzy nowoczesnymi formami dyskursu akademickiego a jego jezuickimi protoplastami istnieje bardzo wiele punktów zbieżnych. Wcześniejszą uwagę na temat podporządkowania obu tradycji retorycznych należy uzupełnić. Oto kolejnym ważkim spoiwem jest fakt, iż współczesny dyskurs akademicki, jak i jego wcześniejsze formy, porządkowane są wedle określonego schematu prezentacji argumentów. Rację zatem miał Ulrich von Wilamowitz-Moellendorf, gdy

\footnotetext{
${ }^{30}$ Przyczyna odwrócenia porządku jest identyczna jak w wypadku tabeli 2.
} 
na początku XX wieku zwracał uwagę na ścisły związek, jaki w tradycji Arystotelesa (a zapewne i Platona) łączył retorykę - jako teorię (i praktykę) konstrukcji tekstu — z logiką jako zbiorem reguł poprawnego rozumowania / wnioskowania ${ }^{31}$.

Raz jeszcze zatem okazuje się, iż uważna analiza „spadku”, jaki zostawili nam przodkowie, może pomóc w zrozumieniu nas samych oraz sposobów, za których sprawą poznajemy świat, oraz następnie dzięki naszemu poznawaniu go opisujemy, bądź przedstawiamy innym ${ }^{32}$.

\section{ANEKS:}

Bibliografia Assertiones za: Karol Estreicher, Bibliografia polska [online], dostęp: 16 września 2010, dostępny: <http://www.estreicher.uj. edu.pl/staropolska/ baza/47492. html>.

Assertiones juris pontificii (?)

47492 Assertiones. Assertiones logicae a Carmelit. Prov. Polon. publ. def. Crac., Andreoviensis. 1654.

47491 Assertiones. Assertiones logicae ex universa Aristotelis dialectica. Ad mentem Angelici ac Ecclesiae doctoris D. Thomae de Aquino decerptae et a FF. Carmelitis Discalceatis prouinciae Polonae Philosophiae studiosis publico certamini expositae. Cracov., in officina typ. Matthiae Andreouiensis. Anno 1634.

47494 Assertiones. Assertiones metheorolog.

47511 Assertiones. Assertiones philosophicae

47510 Assertiones. Assertiones philosophicae de anima per Carmelit. Discalc. Cracoviae, 1686.

47499 Assertiones. Assertiones philosophicae ex octo phisicorum libris, defendendae in Collegio Soc. Jesu Vilnensi, sub autumnalem studiorum renovationem An. Dni 1579. Vilnae, an. a Chr. nato 1579. typ. ill. DD. Nic. Chr. Radivili ducis etc. Joann. Slecki excudebat.

47498 Assertiones. Assertiones philosophicae ex praecipuis totius philosophiae Aris-

\footnotetext{
${ }^{31}$ Zob. U. von Wilamowitz-Moellendorf, Die griechische Literatur des Altertums, [w:] Die griechische und lateinische Literatur und Sprache, wyd. P. Hinneberg, Berlin, Leipzig: B.G. Teubner, 1905, s. 101: [Rhetorik] die Theorie der Rede, soweit mit der Logik zusammenhängt, hatte Aristoteles wissenschaftlich fundiert ([Retoryka] teoria mowy, tak dalece związana z logiką, została naukowo ugruntowana przez Arystotelsa). ${ }^{32}$ Dobitnie pisze o tym m.in. Donald C, Bryant, Aspects of the Rhetorical Tradition - I: The Intellectual Foundation, "The Quarterly Journal of Speech", vol. 36: 1950, nr 2, s. 169-176; tenże, Aspects of the Rhetorical Tradition - II: Emotion, Style, and Literary Association, "The Quarterly Journal of Speech", vol. 36: 1950, nr 3, s. 326-332; wskazuje w tymże artykule nie tylko na tradycję kształtującej sie od 1925 roku tzw. „krytyki retorycznej” (rhetorical criticism), ale i na praktyczny aspekt wykorzystania retoryki w procesie kształcenia uniwersyteckiego w USA. W pełni idee te znalazły odbicie szczególnie w pracach badaczy związanych z K. Burkiem, zob. C. M. Ornatowski, Nauczanie retoryki w USA: orientacje, założenia, praktyka, [w:] Uwieść stowem, czyli retoryka stosowana, red. J. Z. Lichański, Warszawa, 2003, s. 13-26 [tu obszerna lititeratura przedmiotu]; także J. Z. Lichański, Edukacja retoryczna w USA: próba oceny, [w:] Dydaktyka retoryki, red. B. Sobczak, H. Zgółkowa, Poznań 2011, s. 183-196.
} 
totelis difficultatibus defendendae in Collegio Vilnensi Soc. Jesu Maii 16, hora 17. Vilnae, typis illustr. N. Chr. Radziuil per Danielem Lâciciü. 1578.

47496 Assertiones. Assertiones philosophicae menstruae ex posteriori De ortu et interitu, et primo De anima, libris Aristotelis, defendendae in Collegio Vilnensi Soc. Jesu 17 die Decembris, hora 21. Vilnae, typis Nic. Chr. Radivili. Excudebat Daniel Lancicius. 1577.

47497 Assertiones. Assertiones philosophicae menstruae ex secundo libro Aristotelis De anima, de iis quae ad sensus exteriores spectant, et ex primo libro Metaphysicae, defendendae in Collegio Vilnensi Soc. Jesu 28 Februarii, hora 21. Vilnae, typis ill. N. Chr. Radzivil per Danielem Lâciciü. 1578.

47495 Assertiones. Assertiones philosophicae menstruae ex sexto, septimo, et octavo libro physicorum Aristotelis discutiendae in Collegio Vilnensi Soc. Jesu, Julii .... hora 17 An. Dni 1577. Ex typogr. Radivili. \{B. r. 1577\}.

47513 Assertiones. Assertiones pro baptismo infantium

47514 Assertiones. Assertiones quorundam qua inter ceteras non paucas affirmant

47515 Assertiones. Assertiones rhetoricae ac philosophicae

47505 Assertiones. Assertiones Scholasticae ex universa philosophia scholastico peripatetica in Conventu Calisiensi Fratrum Minorum de Observantia S. P. Francisci publicae concertationi expositae. Anno Domini 1770.

26317 Assertiones. Assertiones selectiores logicae.

47540 Assertiones. Assertiones theologicae (ex theologia)

47523 Assertiones. Assertiones theologicae de charitate ex secunda secundae divi Thomae, in Collegio Vilnensi Societatis Jesu disputandae die (dopisano: 16) Octobr. hora (dopisane 8). [Niżej godło Jezuitów; u dołu:] Vilnae, anno a Christo nato 1579. typis illustr. d. d. Nicolai Christophori Radziuili, ducis etc. Joannes Slecki excudebat. 26322 Assertiones. Assertiones theologicae de Christi in terris ecclesia.

47518 Assertiones. Assertiones theologicae de sacro sancto et vivifico missae sacrificio. Vilnae, typ. Nic. Christ. Radiwilli, Dan. Lancicius excudebat. 1576.

47529 Assertiones. Assertiones theologicae de scientia, voluntate, praedestinatione ac reprobatione divina. Ex PP. scien. theologicae D. Thomae doctoris Angelici decerptae et a Carmelitis discalceatis Seminarii Vilnensis publico certamini expositae. Anno Domini 1639. mens. (dopis. Junio), die (dopis 26), hora (dopis 2), post meridiem. Vilnae, Anno Dni 1639.

26323 Assertiones. Assertiones theologicae de trino et uno Deo [...] 1581.

47525 Assertiones. Assertiones theologicae de trino et uno Deo adversus novos Samosatenicos. Ex praelectionibus Collegii Posnaniensis praeteriti semestris excerptae. Discutiendae Octobris, die... hora... (nie wypełnione). Posnaniae, in officina Joannis Wolrhabii. An. Dni MDLXXXI (1581).

47526 Assertiones. Assertiones theologicae de trino et uno Deo, adversus novos Samosatenicos. Ex praelectionibus Collegii Posnaniensis excerptae. Una cum animadversionibus Fausti Socini Senensis. Quae plenae responsionis loco esse possunt. Editio secunda. Racoviae, typis Sebastiani Sternacii. 1611. 
47527 Assertiones. Assertiones theologicae de trino et uno Deo, adversus novos Samosatenicos. Ex praelectionibus Collegii Posnaniensis excerptae. Una cum animadversionibus Fausti Socini Senensis. Quae plenae responsionis loco esse possunt. Editio tertia. Racoviae, typ. S. Sternacyi, 1618.

26324 Assertiones. Assertiones theologicae de trino et uno Deo... 1582;

26325 *Assertiones. Assertiones theologicae de trino et uno Deo... 1611;

26326 *Assertiones. Assertiones theologicae de trino et uno Deo... 1618;

47520 Assertiones. Assertiones theologicae de usu. Sacrosancti Eucharistiae Sacramenti ac primum quidem de veritate et necessitate communicandi, deinde vero de hujus mysterii integritate sub una specie, propositae in Colleg. Posnanien. Soc. Jesu in autumnali studiorum renovatione. Anno Dni 1577. Joan. VI. Nisi manducaveritis carnem filij hominis et biberitis ejus sanguinem, non habebitis vitam in vobis, et qui manducat me et ipse vivet propter me. Discutientur mensis Octobris die (dopisane 16). Posnaniae, ex officina Melchioris Neringk. Anno Domini 1577.

47519 Assertiones. Assertiones theologicae de vera et reali corporis Christi in Eucharistia praesentia. Propositae in Collegio Posnaniensi Soc. Jesu in verna studiorum renovatione. Posnaniae, excudebat Melchior Neringk. An. 1577. 